\title{
INSTRUMEN TES ISLAM KIMIA (ITIK) UNTUK MENDETEKSI PEMAHAMAN LEVEL MIKROSKOPIS MATERI AIR
}

\author{
Asih Widi Wisudawati* \\ *Jurusan Pendidikan Kimia FST UIN Sunan Kalijaga \\ e-mail: asihwisudawati@yahoo.comdan198409012009122004@uin-suka.ac.id,
}

\begin{abstract}
The study aims to develop instrument to measurethe level of understanding of students and microscopic level material phase changes of water. The method used is $R \& D$ (Research and Development) Borg and Gall, which have procedure were are following step (1) Need assessment/ Plan (2) Design product/ Organization (3) Created product/ implementation. Implementation with one shot design study with samples used a number of 71 students of $10^{\text {th }}$ grade MA Wahid Hasyim and senior high school MBS Yogyakarta. Indicators in the study is the movement and vibration of water particles, the distance between water particles, particle kinetic energy of water, relative atomic mass of water and hydrogen bonding. The results showed an understanding of chemica lmaterial microscopic level is low and spitual attitude as a nurturant effect is high categories.
\end{abstract}

Keywords: Instruments test, a microscopic representation, water

\section{PENDAHULUAN}

Pondok pesantren merupakan fenomena tersendiri dalam sejarah pendidikan di Indonesia. Hal ini disebabkan pondok pesantren adalah suatu lembaga pendidikan yang unik dan merupakan pioner lembagalembaga pendidikan formal sekarang ini. Pondok pesantren pada awalnya menawarkan ilmu-ilmu keislaman saja tetapi seiring dengan perkembangan jaman sekarang pondok pesantren juga menawarkan ilmu-ilmu umum. Sehingga pondok pesantren sangat beraneka ragam, salah satunya bisa dikategorikan pondok pesantren salafiah dan pondok pesantren modern.

Salah satu bentuk pengembangan keilmuan umum di Pondok Pesantren adalah dengan mendirikan institusi pendidikan yang dinamakan Madrasah. Salah satu pondok pesantren adalah Pondok Pesantren Wahid Hasyim dan Pondok Pesantren Muhammadiyah Boarding School (MBS). Di pondok ini terdapat MTs dan MA diajarkan ilmu-ilmu agama dan ilmu-ilmu umum dalam waktu bersamaan. Ilmu-ilmu umum misalnya mata pelajaran kimia setingkat MA/SMA diberikan dalam waktu yang cukup terbatas. Oleh sebab itu keterbatasan waktu untuk mempelajari ilmu kimia diantisipasi dengan belajar secara mandiri.
Seorang santri sebenarnya telah membawa suatu konsep sendiri yang bisa mereka peroleh dari pengalaman sebelumnya atau disebut konsep awal. Sehingga pada saat seorang anak harus mengkaji ilmu secara mandiri terjadi proses pengkaitan konsep awal dengan materi baru, yang terkadang bisa terjadi pemahaman anak/ konsep alternatif yang diyakini anak itu benar tetapi berbeda dengan konsep para ahli yang dinamakan miskonsepsi. Proses belajar mandiri bagi siswa yang tinggal di pondok pesantren memungkinkan siswa salah mengkonstruk materi kimia yaitu perubahan wujud air. Proses mengkonstruk materi perubahan wujud air memerlukan representasi level mikroskopis. Jika siswa berhasil mengkonstruk konsep perubahan wujud air pada tingkat mikroskopis maka siswa tersebut akan berhasil memahami konsep-konsep kimia yang lain. Perubahan wujud air merupakan suatu proses perubahan fisis yang dipengaruhi oleh energi kinetik yang dimiliki oleh molekul air.

Berdasarkan data-data dan kondisi tersebut di atas perlu diketahui tingkat kemampuan pemahaman konsep kimia pada siswa SMA/MA yang berada di pondok pesantren dengan aktivitas yang padat. Informasi tentang tingkat pemahaman kimia tentang representasi level mikroskopis pada 
konsep perubahan wujud air yang terintegrasi Islam-Kimia untuk mengukur sikap spiritual setelah mempelajari konsep kimia pada siswa yang belajar di pondok pesantren perlu diketahui.Representasi mikroskopis merupakan level abstrak yang menjelaskan fenomena makroskopis (Indrayani at al, 2013). Proses visualisasi konsep dalam merepresentasikan fenomena yang kompleks dan tidak dapat diamati berkontribusi pada pembentukan pengetahuan sains (Maria Evagorou at al, 2015). Penelitian oleh Chistopher Horton (2004) dengan judul "Student alternative conception in Chemistry" telah menemukan berbagai konsep yang salah/ konsep alternatif siswa yang berbeda dengan teori. Mustafa Tuysuz at al (2011) meneliti bagaimana calon guru kimia menggunakan konsep tiga tingkatan yaitu makroskopis, mikroskopis dan simbolis dalam proses pembelajaran yang calon guru lakukan, hasilnya adalah calon guru masih kasulitan dalam mengintegrasikan ketiga level tersebut dalam proses pembelajaran perubahan fase dan larutan, calon guru tersebut menggunakan demonstrasi, ceramah, dan eksperimen untuk mengajar level makroskopis. Abd Halim at al (2013) melakukan penelitian pendahuluan dalam melihat mental model peserta didik pada materi ikatan kimia, hasilnya menunjukkan kesulitan dalam menghubungkan tiga level dalam menyusun model mental materi ikatan kimin hal ini disebabkan karena pada materi ikatan peserta didik tidak melihat secara langsung bentuk atom dan pola interaksinya. Inilah yang melatar belakangi peneliti untuk mengkaji pemahaman konsep pada reperesentasi level mikroskopis perubahan wujud air yang dapat meningkatkan sikap spiritual siswa diterapkan dalam pondok pesantren.

Konsep dalam kamus bahasa Indonesia adalah gambaran mental dari objek atau apapun yang ada di luar bahasa yang digunakan oleh akal budi untuk memahami hal-hal lain. Sementara itu Slavin (1997:251), menyatakan konsep sebagai abstraksi dari pemikiran (ide) yang merupakan ganeralisasi dari sesuatu yang khusus (spesifik).Seringkali pelajar dalam kegiatan belajar hanya menghafal suatu konsep tanpa memperhatikan hubungan dengan konsep sebelumnya. Hal ini mengakibatkan konsep baru tidak masuk ke jaringan konsep dalam kepala siswa, tetapi berdiri sendiri tanpa hubungan dengan konsep yang lain maka konsep tersebut tidak mempunyai arti sebab arti konsep berasal dari hubungan dengan konsep lain (Berg,1991:9). Jadi belajar konsep adalah suatu proses aktif anak dalam membentuk jaringan konsep dalam kepala mereka dengan menghubungkan dengan konsep-konsep sebelumnya sehingga mempunyai arti.

Proses pemahaman konsep kimia untuk peserta didik melalui proses representasi materi kimia. Proses representasi kimia terdiri atas representasi makroskopis, mikroskopis, dan simbolis. Berdasarkan latar belakang penelitian dapat dirumuskan beberapa masalah sebagai berikut:Bagaimana karakteristik proses dan produk instrumen tes untuk mengukur representasi mikroskopis peserta didik?Bagaimana pemahaman konsep level mikroskopis peserta didik di pondok pesantren dan sikap spiritual diukur dengan Instrumen Tes Islam-Kimia (ITIK) ?

\section{METODE}

Desain eksperimen ini merupakan bagian dari metode penelitian dan pengembangan (Research and Development/ R\&D) Borg \& Gall (2003) untuk menghasilkan produk-produk pendidikan yaitu instrumen tes. Tahapan penelitian yang dilaksanakan adalah tahapan need assesment untuk memperoleh prototype desain product yang akan dikembangkan, pengorganisasian/ memformulasi indikator (Tabel 1) yang akan dicapai dari instrumen yang dikembangkan, pelaksanaan penyusunan instrumen, review dari expert judgment dan implementasi dari pengembangan. Desain eksperimen yang digunakan untuk implementasi/ uji coba lapangandengan model Single one shot Case Study. Sampel yang digunakan adalah dua madrasah yang terintegrasi dalam pondok pesantren. Madrasah yang digunakan sebagai sampel penelitian ini adalah peserta didik kelas X MA Wahid Hayim di Pondok Pesantren Wahid Hasyim Yogyakarta dan Peserta didik kelas X SMA Muhammadiyah Boarding School (MBS) di Pondok pesantren Modern Muhammadiyah Boarding School (MBS) Yogyakarta. 
Tabel 1.

Kisi-kisi Instrumen Tes Islam Kimia (ITIK)

\begin{tabular}{|c|c|c|c|}
\hline $\begin{array}{l}\text { Kompeten- } \\
\text { si Dasar } \\
(\mathrm{KD})\end{array}$ & $\begin{array}{l}\text { Uraian } \\
\text { materi }\end{array}$ & $\begin{array}{l}\text { Indikator } \\
\text { Pencapaian }\end{array}$ & $\begin{array}{l}\text { No. } \\
\text { Soa } \\
1\end{array}$ \\
\hline $\begin{array}{l}\text { Menyadari } \\
\text { adanya } \\
\text { keteraturan } \\
\text { struktur } \\
\text { partikel } \\
\text { materi } \\
\text { sebagai } \\
\text { wujud } \\
\text { kebesaran } \\
\text { Tuhan } \\
\text { YME dan } \\
\text { pengetahu- } \\
\text { an tentang } \\
\text { struktur } \\
\text { partikel } \\
\text { materi } \\
\text { sebagai } \\
\text { hasil } \\
\text { pemikiran } \\
\text { kreatif } \\
\text { manusia } \\
\text { yang } \\
\text { kebenaran- } \\
\text { nya } \\
\text { bersifat } \\
\text { generik }\end{array}$ & $\begin{array}{l}\text { Tafsir } \\
\text { QS.al- } \\
\text { Anbiya' } \\
\text { ayat } 30\end{array}$ & $\begin{array}{l}\text { Meyakini } \\
\text { makna QS.al- } \\
\text { Anbiya' ayat } \\
30\end{array}$ & $\begin{array}{l}1, \\
2,3, \\
4, \\
5, \\
6,7, \\
8, \\
9, \\
10\end{array}$ \\
\hline \multirow{3}{*}{$\begin{array}{l}\text { Memban- } \\
\text { dingkan } \\
\text { proses } \\
\text { pembentuk } \\
\text { an ikatan } \\
\text { ion, ikatan } \\
\text { kovalen, } \\
\text { ikatan } \\
\text { kovalen } \\
\text { koordinasi, } \\
\text { dan ikatan } \\
\text { logam serta } \\
\text { interaksi } \\
\text { antar } \\
\text { partikel } \\
\text { (atom, ion, } \\
\text { dan } \\
\text { molekul) } \\
\text { materi dan } \\
\text { hubungan- } \\
\text { nya dengan } \\
\text { sifat fisik } \\
\text { materi. }\end{array}$} & $\begin{array}{l}\text { Gerakan } \\
\text { dan } \\
\text { getaran } \\
\text { Partikel } \\
\text { air }\end{array}$ & $\begin{array}{l}\text { Menjelaskan } \\
\text { gerakan } \\
\text { partikel air } \\
\text { dalam tiga } \\
\text { fasa dalam } \\
\text { visualisasi } \\
\text { gambar }\end{array}$ & $\begin{array}{l}2,4, \\
5\end{array}$ \\
\hline & $\begin{array}{l}\text { Jarak } \\
\text { partikel } \\
\text { air }\end{array}$ & $\begin{array}{l}\text { Menjelaskan } \\
\text { jarak antar } \\
\text { molekul air } \\
\text { dalam tiga } \\
\text { fasa } \\
\text { (padat/es, } \\
\text { cair,gas) } \\
\text { dengan } \\
\text { gambar }\end{array}$ & $\begin{array}{l}1,1 \\
0\end{array}$ \\
\hline & $\begin{array}{l}\text { Energi } \\
\text { partikel } \\
\text { air (Ek) }\end{array}$ & $\begin{array}{l}\text { Menjelaskan } \\
\text { energi kinetik } \\
\text { yang } \\
\text { menyertai } \\
\text { pada } \\
\text { perubahan } \\
\text { fasa } \\
\text { (padat/es, }\end{array}$ & $\begin{array}{l}6,7, \\
9\end{array}$ \\
\hline
\end{tabular}

\begin{tabular}{|c|c|c|c|}
\hline $\begin{array}{l}\text { Kompeten- } \\
\text { si Dasar } \\
\text { (KD) }\end{array}$ & $\begin{array}{l}\text { Uraian } \\
\text { materi }\end{array}$ & $\begin{array}{l}\text { Indikator } \\
\text { Pencapaian }\end{array}$ & $\begin{array}{l}\text { No. } \\
\text { Soa } \\
1\end{array}$ \\
\hline & & cair,gas) & \\
\hline & $\begin{array}{l}\text { Massa } \\
\text { molekul } \\
\text { relative } \\
(\mathrm{Mr})\end{array}$ & $\begin{array}{l}\text { Menjelaskan } \\
\text { berat partikel } \\
\text { air pada tiga } \\
\text { fasa } \\
\text { (padat/es, } \\
\text { cair,gas) } \\
\text { dengan } \\
\text { visualisasi } \\
\text { gambar }\end{array}$ & 8, \\
\hline & $\begin{array}{l}\text { Ikatan } \\
\text { Hidrogen } \\
\text { antar } \\
\text { partikel } \\
\text { air }\end{array}$ & $\begin{array}{l}\text { Menggambar } \\
\text { kan kekuatan } \\
\text { ikatan } \\
\text { hydrogen } \\
\text { pada tiga fasa } \\
\text { (padat/es, } \\
\text { cair,gas) } \\
\text { dengan } \\
\text { visualisasi. }\end{array}$ & 3 \\
\hline \multicolumn{3}{|l|}{ Jumlah soal } & 10 \\
\hline
\end{tabular}

Instrumen yang digunakan dalam penelitian ini adalah instrumen validasi untuk produk yang diisi oleh expert. Data yang dihasilkan adalah data dari expert dan data hasil pekerjaan peserta didik dan data respon peserta didik. Data dari expert judgment di analisis secara diskriptif dengan hasil akhir berupa kategori. Selanjutnya, instrumen soal yang dikembangkan secara empiris dianalisis butir soal pada aspek tingkat kesukaran soal dan daya pembeda. Secara empiris soal tidak dihitung validitas dan reliabilitasnya, hal ini disebabkan karena instrumen yang dikembangkan berfungsi sebagai tes diagnostik sehingga baik secara eksternal maupun internal kurang sesuai jika dihitung secara empiris/ uji lapangan. Validitas instrumen yang dikembangkan adalah melalui validitas isi dan validitas konstruk

Langkah-langkah analisis data dari expert judgment sebagai berikut :

a. Data yang diperoleh ditabulasi untuk setiap komponen dan subkomponen dari butir penilaian yang tersedia dalam skala persepsi. Nilai kualitatif diubah menjadi kuantitatif dengan ketentuan, yaitu: $\mathrm{SB}=5$, $\mathrm{B}=4, \mathrm{C}=3, \mathrm{~K}=2$, dan $\mathrm{SK}=1$. 
b. Setelah data terkumpul, kemudian menghitung skor rata-rata dengan rumus: $\bar{X}=\frac{\Sigma X}{n}$

Keterangan :

$$
\begin{array}{ll}
\overline{\mathrm{X}} & =\text { skor rata-rata } \\
\Sigma \mathrm{X} & =\text { jumlah skor } \\
\mathrm{n} & =\text { jumlah penilai }
\end{array}
$$

c. Mengubah skor rata-rata menjadi nilai kuantitatif dengan kriteria penilaian ideal sebagai berikut (Sukarjo \& Sari, 2008: 86):

\begin{tabular}{|c|c|c|c|c|c|c|c|c|}
\hline No & Rentang skor & Kategori & \multicolumn{6}{|c|}{ Tabel 4. Hasil Validasi Expert Judgment } \\
\hline 1 & $\bar{x}+1,8 \quad \mathrm{SB} i<\mathrm{X}$ & Sangat baik & \multirow{2}{*}{ No } & \multirow{2}{*}{ Aspek } & \multicolumn{2}{|l|}{$\begin{array}{l}\text { Dosen } \\
\text { Fisika }\end{array}$} & \multicolumn{2}{|c|}{$\begin{array}{l}\text { Ahli Integrasi } \\
\text { Islam Sains }\end{array}$} \\
\hline 2 & $\bar{x}+0,6 \mathrm{SB} i<\mathrm{X} \leq \bar{x}+1,8 \mathrm{SB} i$ & Baik & & & $\begin{array}{l}\text { Total } \\
\text { Skor }\end{array}$ & Kategori & $\begin{array}{l}\text { Total } \\
\text { Skor }\end{array}$ & $\begin{array}{l}\text { Kate- } \\
\text { gori }\end{array}$ \\
\hline 3 & $\bar{x}-0,6 \mathrm{SB} i<\mathrm{X} \leq \bar{x}+0,6 \mathrm{SB} i$ & Cukup & 1 & Materi & 9 & B & 7 & $\mathrm{C}$ \\
\hline 4 & $\bar{x}-1,8 \mathrm{SB} i<\mathrm{X} \leq \bar{x}-0,6 \mathrm{SB} i$ & Kurang & 2 & $\begin{array}{l}\text { Konstruk- } \\
\text { si Soal }\end{array}$ & 17 & B & 15 & $\mathrm{C}$ \\
\hline \multirow{3}{*}{5} & & & 3 & Bahasa & 11 & A & 11 & $\mathrm{~A}$ \\
\hline & $\mathrm{X} \leq \bar{x}-1,8 \mathrm{SB} i$ & Sangat Kurang & 4 & $\begin{array}{l}\text { Tampilan } \\
\text { Instrumen }\end{array}$ & 8 & $\mathrm{C}$ & 10 & $\mathrm{~B}$ \\
\hline & & & \multicolumn{2}{|c|}{ Jumlah } & 45 & $\mathrm{~B}$ & 43 & $\mathrm{~B}$ \\
\hline
\end{tabular}

\begin{tabular}{|l|l|lr|}
\hline No. & $\begin{array}{l}\text { Tahapan } \\
\text { Produk }\end{array}$ & Deskripsi spesifikasi Produk \\
\hline 3. & $\begin{array}{l}\text { Instrumen } \\
\text { Tes Islam } \\
\text { Kimia } \\
\text { Tahap 3 }\end{array}$ & $\begin{array}{l}\text { Produk ketiga yang } \\
\text { dikembangkan dari reviewer } \\
\text { dosen kimia fisika, ahli TIK, dan } \\
\text { Reviewer dari LP2M berupa } \\
\text { pilihan ganda 10 soal disertai } \\
\end{array}$ & $\begin{array}{l}\text { alasan tertutup dan dilengkapi } \\
\text { dengan potongan surat An-Abiya' } \\
\text { ayat 30 dengan spesifikasi } \\
\end{array}$ \\
& $\begin{array}{l}\text { menggunakan computer based } \\
\text { dengan aplikasi Adobe Flash CS 8 } \\
\text { dilengkapi data base software } \\
\text { XAMPP yang diletakkan di } \\
\text { http://localhost/itik/jawaban.php }\end{array}$ \\
&
\end{tabular}

Tabel 2. Kriteria penilaian ideal

\section{HASIL DAN PEMBAHASAN}

Proses pengembangan instrumen tes Islam Kimia melalui proses sebagai berikut:

Tabel 3. Proses Pengembangan Produk

\begin{tabular}{|l|l|lr|}
\hline No. & $\begin{array}{l}\text { Tahapan } \\
\text { Produk }\end{array}$ & \multicolumn{3}{|l|}{ Deskripsi spesifikasi Produk } \\
\hline 1. & $\begin{array}{l}\text { Instrumen } \\
\text { Tes Islam- } \\
\text { Kimia } \\
\text { Tahap 1 }\end{array}$ & $\begin{array}{l}\text { Produk pertama } \\
\text { dikembangkan berupa } \\
\text { pilihan ganda disertai ang } \\
\text { tertutup dan } \\
\text { dilengkapi dengan potongan surat } \\
\text { An-Abiya ayat 30 dengan } \\
\text { spesifikasi soal diprint out di } \\
\text { kertas A4 atau paper based }\end{array}$ \\
\hline 2. & $\begin{array}{l}\text { Instrumen } \\
\text { Tes Islam- } \\
\text { Kimia } \\
\text { Tahap 2 }\end{array}$ & $\begin{array}{l}\text { Produk kedua yang dikembangkan } \\
\text { dari reviewer dosen kimia fisika } \\
\text { dan ahli TIK berupa pilihan ganda } \\
\text { 12 soal disertai alasan tertutup dan } \\
\text { terbuka serta dilengkapi dengan } \\
\text { potongan surat An-Abiya' ayat 30 } \\
\text { dengan spesifikasi menggunakan } \\
\text { computer based dengan aplikasi } \\
\text { Adobe Flash CS 8. }\end{array}$ \\
\hline
\end{tabular}

Hasil Implementasi di MA Wahid Hasyim dan SMA MBS yogyakarta. Instrumen Tes Islam Kimia (ITIK) sejumlah 10 paket soal yang terdiri atas stem soal, jawaban, alasan, dan derajat keyakinan telah diujicobakan pada 71 peserta didik. Instrumen yang dikembangkan digunakan untuk mengukur kemampuan representasi level mikroskopis materi perubahan wujud air. Instrumen yang dikembangkan dapat digunakan sebagai tes untuk mengetahui prior knowledgel pengetahuan awal siswa tentang konsep atom dan molekul.

Hasil ujicoba lapangan operasional yang telah dilaksanakan diperoleh rentang skor yang diperoleh antara nol (0) sampai enam (6) disajikan pada gambar 1. Hasil tersebut menunjukkan kemampuan awal/ Prior knowledge peserta didik pada materi atom dan molekul tergolong rendah. Pola sebaran jawaban dan alasan peserta didik di MA Wahid Hasyim dan SMA MBS Yogyakarta yang terdiri dari pola Jawaban Benar- Alasan Benar, Jawaban Salah-Alasan Benar, Jawaban Benar-Alasan Salah, Jawaban Salah-Alasan 
Salah di sajikan pada Tabel 5. Pola sebaran jawaban peserta didik pada tingkat pengukuran sikap spiritual pada seluruh butir tes disajikan pada Gambar 2.

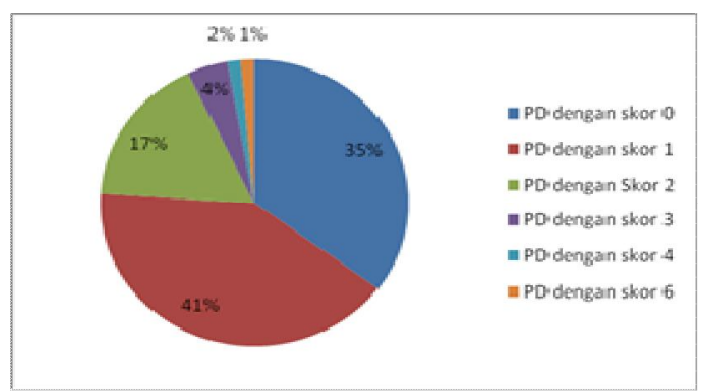

Gambar 1. Persentase jumlah peserta didik yang menjawab benar dan alasan benar

Tabel 5. Pola Sebaran jawaban dan alasan peserta didik di MA Wahid Hasyim dan SMA MBS Yogyakarta

\begin{tabular}{|r|c|c|c|c|}
\hline $\begin{array}{l}\text { No } \\
\text { butir }\end{array}$ & $\begin{array}{l}\text { Jawaban- } \\
\text { alasan } \\
\text { benar }\end{array}$ & $\begin{array}{l}\text { jawaban } \\
\text { salah- } \\
\text { alasan } \\
\text { benar }\end{array}$ & $\begin{array}{l}\text { Jawaban } \\
\text { benar- } \\
\text { alasan } \\
\text { salah }\end{array}$ & $\begin{array}{l}\text { jawaba } \\
\text { n salah- } \\
\text { alasan } \\
\text { salah }\end{array}$ \\
\hline 1 & 8 & 3 & 1 & 59 \\
\hline 2 & 10 & 15 & 19 & 27 \\
\hline 3 & 2 & 6 & 3 & 60 \\
\hline 4 & 25 & 8 & 24 & 14 \\
\hline 5 & 13 & 14 & 16 & 28 \\
\hline 6 & 3 & 2 & 7 & 59 \\
\hline 7 & 6 & 11 & 20 & 34 \\
\hline 8 & 2 & 4 & 2 & 63 \\
\hline 9 & 2 & 12 & 1 & 56 \\
\hline 10 & 1 & 16 & 9 & 45 \\
\hline
\end{tabular}

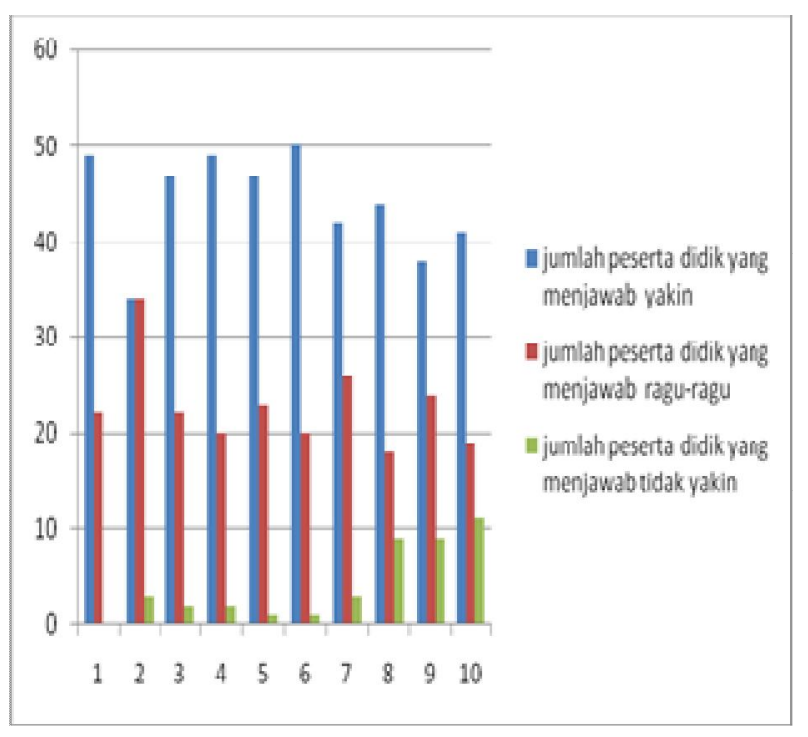

Gambar 2. Pola Sebaran Jawaban Peserta Didik pada Tingkat Pengukuran Sikap Spiritual pada Seluruh Butir Tes

Respon peserta didik terhadap instrumen tes yang dikembangkan diukur berdasarkan aspek konstruksi soal, tampilan soal, dan efek pengiring dari instrumen yang dikembangkan terhadap sikap spiritual disajikan pada Tabel 6. Selain mengukur respon peserta didik terhadap instrumen, peserta didik diminta memberikan masukan terhadap pengintegrasian konsep Islam-Sains dengan menyebutkan surat dalam Al-Quran yang mendeskripsikan konsep air. Daftar surat yang disebutkan oleh responden disajikan pada Tabel 6.

Tabel 6. Surat-surat yang ada di Al-Quran yang Menjelaskan tentang Air Berdasarkan Respon Peserta Didik

\begin{tabular}{|l|l|l|}
\hline $\begin{array}{l}\text { No } \\
\text { yang } \\
\text { menjelaskan } \\
\text { tentang air }\end{array}$ & $\begin{array}{l}\text { Keterangan } \\
30\end{array}$ & $\begin{array}{l}\text { Yl Mulk ayat } \\
\text { berarti:"Katakanlah } \\
\text { (Muhammad)"Terang- } \\
\text { kanlah kepadaku jika } \\
\text { sumber air kamu } \\
\text { menjadi kering; maka } \\
\text { siapa yang akan } \\
\text { memberimu air yang } \\
\text { mengalir" }\end{array}$ \\
\hline 1 & $\begin{array}{l}\text { Al Baqoroh } \\
\text { ayat 60 }\end{array}$ & $\begin{array}{l}\text { Yang berarti :"Ketika } \\
\text { Musa memohon air } \\
\text { untuk kaumnya, Kami } \\
\text { berfirman "pukullah } \\
\text { batu dengan } \\
\text { tongkatmu" lalu } \\
\text { memancarlah daripada } \\
\text { dua belas mata air. } \\
\text { sungguh tiap suku telah } \\
\text { mengetahui tempat } \\
\text { minumnya masing- } \\
\text { masing, makan dan } \\
\text { minumlah dari rezeki } \\
\text { yang diberikan Allah, } \\
\text { dan janganlah kamu } \\
\text { berkeliaran di bumi } \\
\text { dengan berbuat } \\
\text { kerusakan" }\end{array}$ \\
\hline 3 & Al-Kausar & $\begin{array}{l}\text { Yang berarti :"sungai di } \\
\text { surga, Allah telah }\end{array}$ \\
\hline
\end{tabular}




\begin{tabular}{|c|c|c|}
\hline No & $\begin{array}{l}\text { Nama surat } \\
\text { yang } \\
\text { menjelaskan } \\
\text { tentang air }\end{array}$ & Keterangan \\
\hline & & $\begin{array}{l}\text { memberikan nikmat } \\
\text { yang banyak maka } \\
\text { diperintahkan untuk } \\
\text { sholat dan berkurban } \\
\text { sebagai ibadah } \\
\text { mendekatkan diri pada } \\
\text { Allah" }\end{array}$ \\
\hline 4 & $\begin{array}{l}\text { An-Naba' ayat } \\
14 \text { dan } 15\end{array}$ & $\begin{array}{l}\text { Yang berarti :"kami } \\
\text { turunkan dari awan air } \\
\text { yang banyak tercurah } \\
\text { supaya Kami } \\
\text { tumbuhkan dengan air } \\
\text { itu biji-bijian dan } \\
\text { tumbuh-tumbuhan" }\end{array}$ \\
\hline 5 & Maryam 24 & $\begin{array}{l}\text { Yang berarti:" maka } \\
\text { Jibril menyerunya dari } \\
\text { tempat rendah, } \\
\text { janganlah kamu } \\
\text { bersedih hati } \\
\text { sesungguhnya Tuhanmu } \\
\text { telah menjadikan anak } \\
\text { sungai di bawahmu" }\end{array}$ \\
\hline 6 & $\begin{array}{l}\text { Al Mu'minun } \\
\text { ayat } 18\end{array}$ & $\begin{array}{l}\text { Yang berarti :"dan } \\
\text { Kami turunkan air dari } \\
\text { langit menurut suatu } \\
\text { ukuran, lalu Kami } \\
\text { jadikan air itu menetap } \\
\text { di Bumi, dan } \\
\text { sesunggungnya Kami } \\
\text { benar-benar berkuasa } \\
\text { menghilangkannya" }\end{array}$ \\
\hline 7 & $\begin{array}{l}\text { An- Nahl ayat } \\
66 \text { dan } 67\end{array}$ & $\begin{array}{l}\text { Yang bermakna } \\
\text { terdapat air/ minuman } \\
\text { yang berasal dari hewan } \\
\text { dan tumbuhan yang } \\
\text { dapat dimanfaatkan } \\
\text { manusia, dalam ayat } \\
\text { tersebut menyebutkan } \\
\text { minuman susu, madu, } \\
\text { dan minuman hasil } \\
\text { fermentasi buah koma } \\
\text { dan anggur yang } \\
\text { memabukkan dan } \\
\text { terdapat manfaat di } \\
\text { dalamnya }\end{array}$ \\
\hline 8 & Ar-Rahman & $\begin{array}{l}\text { Terdapat ayat yang } \\
\text { berarti:" di surga } \\
\text { terdapat dua mata air } \\
\text { yang memancar, maka } \\
\text { nikmat Tuhanmu }\end{array}$ \\
\hline
\end{tabular}

\begin{tabular}{|c|c|c|}
\hline $\begin{array}{l}\text { No } \\
\text {. }\end{array}$ & $\begin{array}{l}\text { Nama surat } \\
\text { yang } \\
\text { menjelaskan } \\
\text { tentang air }\end{array}$ & Keterangan \\
\hline & & $\begin{array}{l}\text { manakah yang kamu } \\
\text { dustakan?" }\end{array}$ \\
\hline 9 & $\begin{array}{l}\text { Al Anbiya' } \\
\text { ayat } 30\end{array}$ & $\begin{array}{l}\text { Yang berarti: "Dan } \\
\text { apakah orang-orang } \\
\text { kafir tidak mengetahui } \\
\text { bahwa langit dan bumi } \\
\text { keduanya dahulu } \\
\text { menyatu, kemudian } \\
\text { Kami pisahkan antara } \\
\text { keduanya; dan Kami } \\
\text { jadikan segala sesuatu } \\
\text { yang hidup berasal dari } \\
\text { air; maka mengapa } \\
\text { tidak beriman?" }\end{array}$ \\
\hline 10 & Al Furqon 48 & $\begin{array}{l}\text { Yang berarti : "Dialah } \\
\text { yang meniupkan angin } \\
\text { (sebagai) pembawa } \\
\text { kabar gembira dekat } \\
\text { sebelum kedatangan } \\
\text { rahmat-Nya (hujan), } \\
\text { dan Kami turunkan dari } \\
\text { langit air yang amat } \\
\text { bersih" }\end{array}$ \\
\hline 11 & $\begin{array}{l}\text { Ibrahim ayat } \\
32\end{array}$ & $\begin{array}{l}\text { Yang berarti: "Allah- } \\
\text { lah yang telah } \\
\text { menciptakan langit dan } \\
\text { bumi dan menurunkan } \\
\text { air hujan dari langit, } \\
\text { kemudian Dia } \\
\text { mengeluarkan dengan } \\
\text { air hujan itu berbagai } \\
\text { buah-buahan menjadi } \\
\text { rezeki untukmu; dan } \\
\text { Dia telah menundukkan } \\
\text { bahtera bagimu supaya } \\
\text { bahtera itu, berlayar di } \\
\text { lautan dengan } \\
\text { kehendak-Nya, dan Dia } \\
\text { telah menundukkan } \\
\text { (pula) bagimu sungai- } \\
\text { sungai.". }\end{array}$ \\
\hline 12 & $\begin{array}{l}\text { Ar Ra'd ayat } \\
17\end{array}$ & $\begin{array}{l}\text { Yang berarti:" Allah } \\
\text { telah menurunkan air } \\
\text { (hujan) dari langit, } \\
\text { maka mengalirlah air di } \\
\text { lembah-lembah } \\
\text { menurut ukurannya, } \\
\text { maka arus itu membawa } \\
\text { buih yang }\end{array}$ \\
\hline
\end{tabular}




\begin{tabular}{|c|c|c|}
\hline No & $\begin{array}{l}\text { Nama surat } \\
\text { yang } \\
\text { menjelaskan } \\
\text { tentang air }\end{array}$ & Keterangan \\
\hline & & $\begin{array}{l}\text { mengembang. Dan dari } \\
\text { apa logam yang mereka } \\
\text { lebur dalam api untuk } \\
\text { membuat perhiasan dan } \\
\text { alat-alat ada (pula) } \\
\text { buihnya seperti buih } \\
\text { arus itu. Demikianlah } \\
\text { Allah membuat } \\
\text { perumpamaan bagi } \\
\text { yang benar dan yang } \\
\text { bathil. Adapun buih itu } \\
\text { akan hilang sebagai } \\
\text { sesuai yang tidak ada } \\
\text { harganya; adapun yang } \\
\text { memberikan manfaat } \\
\text { bagi manusia maka ia } \\
\text { akan tetap di Bumi, } \\
\text { Demikianlah Allah } \\
\text { membuat perumpaman" }\end{array}$ \\
\hline 13 & Yunus ayat 24 & $\begin{array}{l}\text { Yang berarti: } \\
\text { "Sesungguhnya } \\
\text { perumpamaan } \\
\text { kehidupan duniawi itu } \\
\text { adalah seperti air } \\
\text { (hujan) yang kami } \\
\text { turunkan dari langit lalu } \\
\text { tumbuhlah dengan } \\
\text { suburnya karena air itu } \\
\text { tanaman-tanaman bumi, } \\
\text { diantaranya ada yang } \\
\text { dimakan manusia dan } \\
\text { binatang ternak..." }\end{array}$ \\
\hline 14 & $\begin{array}{l}\text { An Naziat ayat } \\
31\end{array}$ & $\begin{array}{l}\text { Yang berarti: " Ia } \\
\text { memancarkan } \\
\text { daripadanya mata } \\
\text { airnya dan } \\
\text { (menumbuhkan) } \\
\text { tumbuh-tumbuhannya" }\end{array}$ \\
\hline
\end{tabular}

Tabel 7. Respon Peserta Didik/ Sampel terhadap Instrumen Tes Islam Kimia

\begin{tabular}{|l|l|l|}
\hline Aspek & $\begin{array}{l}\text { Skor yang } \\
\text { diperoleh }\end{array}$ & Kategori \\
\hline Konstruksi soal & 33.33 & Sedang \\
\hline Tampilan soal & 43.5 & Sedang \\
\hline Sikap Spiritual sebagai & 67 & Tinggi \\
\hline
\end{tabular}

efek pengiring

Tabel 8. Analisis Butir Soal pada Tingkat

Kesukaran dan Daya Pembeda soal

\begin{tabular}{|r|r|l|r|l|}
\hline & \multicolumn{2}{|c|}{$\begin{array}{l}\text { Tingkat } \\
\text { Kesukaran }\end{array}$} & \multicolumn{2}{c|}{ Daya Pembeda } \\
\hline $\begin{array}{r}\text { No } \\
\text { butir }\end{array}$ & Skor & Kategori & skor & Kategori \\
\hline 1 & 0.13 & sukar & 0.26 & cukup \\
\hline 2 & 0.41 & sedang & 0.47 & baik \\
\hline 3 & 0.07 & sukar & 0.11 & jelek \\
\hline 4 & 0.68 & sedang & 0.32 & cukup \\
\hline 5 & 0.32 & sedang & 0.32 & cukup \\
\hline 6 & 0.14 & sukar & 0.32 & cukup \\
\hline 7 & 0.35 & sedang & 0.16 & jelek \\
\hline 8 & 0.04 & sukar & 0.11 & jelek \\
\hline 9 & 0.04 & sukar & 0.11 & jelek \\
\hline 10 & 0.13 & sukar & 0.37 & cukup \\
\hline
\end{tabular}

Kemampuan representasi level mikroskopis peserta didik pada materi atom dan molekul merupakan salah prasyarat untuk memahami konsep atom dan molekul lebih lanjut. Karakteristik materi atom dan molekul yang termasuk abstrak menuntut peserta didik dapat memulai dari level mikroskopis. Konsep kimia sangat tergantung pada pola representasi yang akan membentuk model mental peserta didik, model mental tersebut dibangun dari percobaan, intepretasi, eksplanasi ketika proses pembelajaran kimia (Abd Halim at al, 2013:225). Proses pembelajaran kimia yang didesain oleh guru mempengaruhi proses pembentukan model mental peserta didik. Dalam melaksanakan proses pembelajaran sangat dipengaruhi oleh psikologi atau karakteristik peserta didik.

Proses pembelajaran yang tidak mendukung pengintegrasian tiga tingkat representasi yaitu makroskopis, simbolis, dan mikroskopis merupakan salah satu celah yang membuat peserta didik menkonstruk konsep yang salah/ naif. Proses pembelajaran kimia harus memperhatikan tiga tingkatan yaitu makroskopis, mikroskopis dan simbolis (Mustafa Tuysuz at al, 2011: 452).

Produk instrumen tes yang digunakan akan dapat mendeteksi pemahaman peserta didik terhadap konsep perubahan wujud zat, meliputi kategori "Paham", "Miskonsepsi", 
dan "Tidak Paham". dan Derajat keyakinan terhadap kebesaran ciptaan Tuhan. Instrumen yang dikembangkan dapat mengklasifikasikan menjadi tiga kategori karena terdiri atas tiga tahapan. Tahapan pertama berbentuk pilihan ganda dengan lima option jawaban. Tahapan kedua merupakan pilihan alasan dan alasan terbuka. tahapan ketiga merupakan derajat keyakinan peserta didik terhadap kebesaran ciptaan Tuhan. Tiga tahapan tersebut diberinama "Three Tire Test".

Instrumen yang dikembangkan bertujuan untuk mengukur pemahaman konsep perubahan wujud zat dalam representasi mikroskopis dengan dilengkapi derajat keyakinan. Instrumen tersebut diberinama Intrumen Tes Islam-Kimia (ITIK). Pemberian nama dimaksudkan untuk mempermudah mengingat dan menggunakan.

Produk Intrumen Tes Islam-Kimia (ITIK) pertama berupa paper based, dimana hasil akhirnya dianalisis guru secara manual. Produk pertama dikembangkan dengan mengimpor gambar dan mengambar gerakan molekul dalam software corel draw. Produk pertama didiskusikan dengan reviewer yang menghasilkan perubahan bentuk produk yang dihasilkan. Hal ini mengingat tujuan penggunaan produk adalah untuk melakukan pengukuran pengetahuan awal peserta didik sebelum pembelajaran dimulai maka produk yang dikembangkan harus praktis dan langsung dapat melihat hasilnya. Produk pertama yang dihasilkan direvisi menjadi produk kedua yang computer based.

Produk kedua yang computer based dikerjakan dengan membuat gambar dengan aplikasi Adobe Flash CS 8 . Produk ini menggunakan penyimpan database dengan format excel untuk mengetahui hasil jawaban peserta didik di http://localhost/itik/jawaban.php. Untuk mengambil nama peserta di http:/localhost/itik/peserta.php. Produk kedua dapat berjalan jika XAMPP dalam keadaan running. Produk ini selanjutnya direview oleh ahli evaluasi dari LP2M. Menurut reviewer tersebut jika produk ini benar-benar computer based maka justifikasi akhir tidak boleh secara manual. Sehingga produk ITIK kedua direvisi supaya hasil akhir yang terdapat di data base di http://localhost/itik/jawaban.php.dapat langsung diputuskan hasil akhirnya.
Validasi isi terhadap produk Instrumen Islam-Kimia dilaksanakan dengan metode expert judgment. Validasi dilakukan oleh dosen kimia fisika dan ahli integrasi Islam Sains. Hasil dari validasi isi, produk Intrumen Islam Kimia oleh dosen kimia fisika untuk aspek materi mendapat kategori B, aspek konstruksi soal kategori $\mathrm{B}$, aspek Bahasa kategori A, aspek tampilan instrument kategori C. Hasil validasi isi oleh ahli integrasi IslamSains untuk aspek materi kategori C, Aspek Konstruksi soal kategori C, Aspek Bahasa kategori A, dan aspek tampilan instrument katergori B. Proses revisi terhadap soal oleh kedua ahli tersebut terhadap konstruksi soal supaya tidak membuat konsep yang ambigu dengan penyesuaian antara kisi-kisi dengan stem soal dan jawaban.

Konsep atom dan molekul merupakan materi yang menuntut representasi mikroskopis. Salah satu bagian dari konsep tersebut adalah konsep perubahan wujud air yang merupakan salah satu perubahan fisika. Instrumen yang dikembangkan dalam penelitian ini adalah konsep molekul air. Indikator yang dicapai dalam instrumen yang dikembangkan adalah gerakan dan getaran partikel air, jarak antar partikel air, Energi Kinetik partikel air, Massa atom relatif air dan Ikatan Hidrogen. Dari indikator-indikator tersebut diterjemahkan dalam 10 (sepuluh) paket soal dengan desain soal three tire test (Tes dengan tiga tingkatan) dengan butir tes dengan jawaban, alasan dan derajat keyakinan untuk mengukur sikap spiritual (Tabel 1).

Hasil ujicoba lapangan operasional di MA Wahid Hasyim dan SMA MBS Yogyakarta memperoleh hasil skor tertinggi peserta didik adalah 6 dan skor terendah adalah 0. Seperti dilihat pada Gambar 2, persentase peserta didik yang pola jawabanalasan benar/ skor 0 adalah $35 \%$, persentase skor peserta didik 1 adalah $41 \%$, persentase skor peserta didik 2 adalah $17 \%$, persentase skor peserta didik 3 adalah $4 \%$, persentase skor peserta didik 4 adalah $2 \%$, dan persentase skor peserta didik 6 adalah $1 \%$. Data tersebut menunjukkan bahwa kemampuan representasi mikroskopis konsep atom dan molekul air tergolong rendah. Peserta didik dengan skor 0 bukan berarti salah semua, akan tetapi tidak memiliki pola jawaban dan alasan yang benar semua. Peserta didik cenderung membuat kesalahan dengan 
pola jawaban benar dengan alasan salah. Jawaban salah dengan alasan benar. Data pola jawaban dapat dilihat pada Tabel 5. Pola Jawaban benar dengan alasan salah atau sebaliknya menunjukkan kekurang pengetahuan peserta didik dalam memahami materi dan dapat mengarahkan pada terbentuknya konsep yang naif atau miskonsepsi peserta didik.

Pada konsep jarak antar molekul air di butir soal nomor 1 dan 10 termasuk kategori soal yang sukar, dengan jumlah peserta didik yang menjawab benar adalah 8 dan 1 peserta didik. Pada konsep gerakan dan getaran molekul air pada butir soal 2, 4, dan 5 termasuk soal sedang, dengan jumlah peserta didik yang menjawab benar adalah 10, 25, dan 13. Energi Kinetik pada molekul air terdapat pada butir 6,7 dan 9 menunjukkan soal dengan kategori sedang dan sukar dengan jumlah peserta didik yang menjawab benar adalah 3 , 6, dan 2. Untuk indikator Masa Molekul relatif air di butir ke 8 menunjukkan soal dengan kategori sukar dengan jumlah peserta didik yang menjawab benar adalah 2. Indikator terakhir adalah ikatan hidrogen yang dibentuk molekul-molekul air pada butir ke 3 menunjukkan soal dengan kategori sukar dengan jumlah peserta didik yang benar adalah 2 .

Sikap spiritual yang ditunjukkan sebagai efek pengiring dari instrumen yang didesain dengan pemodelan atom dan molekul air dengan Flash CS 8 tergolong pada kategori yang tinggi. Hasil tersebut didukung dengan surat-surat dalam Al-Quran yang diberikan peserta didik yang menggambarkan materi air seperti pada Tabel 6. Kandungan semua surat yang diberikan oleh responden menunjukkan bahwa air memiliki kedudukan yang utama dalam kehidupan manusia. Air merupakan asal mula adanya kehidupan seperti pada QS Al Anbiya. Air diciptakan Allah menurut ukuran masing-masing seperti pada QS Al Mu'minun(18) dan Ar Ra'd(17). Kata "Ukuran" dapat disejajarkan dengan konsep atom dan molekul sebagai sebuah konsorsium keilmuan kimia sebagai sebuah molekul air. molekul air memiliki bentuk atau ukuran yang berbeda telah diteliti oleh ilmuan jepang Masaru Emoto. Masaru Emoto dalam penelitiannya memperoleh foto kristal air dalam berbagai bentuk akibat dari respon positif dan negatif. Data penelitian pada
Gambar 3 menunjukkan peserta didik cenderung memilih "Yakin". Rata-rata per butir soal jumlah peserta didik yang memilih yakin sejumlah 44 orang atau $62.8 \%$ dari keseluruhan responden. Peserta didik yakin bahwa setelah melihat animasi pemodelan molekul air lebih meningkatkan keimanan dan percaya bahwa Allah menciptakan air dalam berbagai ukuran molekul dan air sebagai sumber kehidupan mulai dari awal penciptaan alam semesta sampai akhir adanya alam semesta(surga).

Peningkatan nilai-nilai spiritual peserta didik akibat dari instrumen yang diberikan dapat memberikan kontribusi yang positif terhadap konstruksi model mental peserta didik pada konsep atom dan molekul air. Model mental yang dibentuk dari proses representasi mikroskopis pada materi perubahan wujud air yang masih tergolong rendah diakibatkan karena kemampuan spasial peserta didik dalam membayangkan bentuk molekul air/ pemodelan masih rendah. Hal ini juga di dukung oleh proses pembelajaran kimia yang cenderung bersifat teoritis dan belum mengintegrasikan tiga tingkatan representasi yaitu Makroskopis, mikroskopis dan simbolis.

\section{SIMPULAN DAN SARAN}

\section{Simpulan}

1. Produk yang berupa Instrumen Tes Three Tire Test (Tes dengan tiga tahapan) untuk mendeteksi pemahaman peserta didik terhadap konsep perubahan wujud air dalam representasi level mikroskopis dan derajat keyakinan terhadap Allah SWT. Instrumen yang dikembangkan digunakan sebagai pretes sebelum pembelajaran konsep atom dan molekul dilaksanakan. Instrumen yang dikembangkan diberi nama "Instrumen Tes Islam Kimia (ITIK)". Proses yang dilaksanakan dalam pengembangan Instrumen Tes Islam Kimia (ITIK) melalui tahapan hasil dari penelitian pendahuluan, hasil dari review Dosen Kimia Fisika, Ahli TIK, dan Ahli Evaluasi. Produk pertama Instrumen Tes Islam Kimia (ITIK) adalah dengan spesifikasi paper based dengan 12 soal, setelah direview terhadap kisi-kisi dan soal dihasilkan 10 soal final dengan gambar yang mendukung. Produk akhir 
dengan spesifikasi computer based dengan soal pilihan ganda dengan alasan terbuka dan tertutup dilengkapi derajat keyakinan terhadap Allah SWT. Produk terakhir dalam penelitian ini adalah 10 soal pilihan ganda dangan alasan tertutup dengan derajat keyakinan terhadap Allah SWT dengancomputerbased menggunakan Adobe Flash CS 8 dengan data based jawaban di http://localhost/itik/jawaban.php

2. Dari hasil implementasi instrumen ITIK diperoleh pemahaman konsep atom dan molekul pada tema perubahan wujud air pada tingkat mikroskopis tergolong rendah dengan persentase peserta didik yang berhasil menjawab benar dengan alasan benar $0,1,2,3,4,6$ butir tes berturut-turut adalah 35\%, 41\%, 17\%, $4 \%, 2 \%$ dan $1 \%$. Sikap spiritual sebagai efek pengiring dari Instrumen Tes Islam Kimia menunjukkan kategori yang tinggi dengan persentase jumlah peserta didik yang memilih "Yakin" setiap butir soalnya adalah $62.8 \%$ dari keseluruhan responden. Hasil dari analisis butir soal menunjukkan butir soal yang dikembangkan tergolong soal sukar dan sedang dan memiliki daya pembeda berada pada rentang jelek sampai baik. Butir soal dengan kategori daya pembeda jelek akan dilakukan revisi pada proses penelitian lebih lanjut.

\section{Saran}

Tingkat pemahaman konsep pada level makroskopis yang tergolong rendah diakibatkan oleh beberapa sebab. Pertama adalah terletak pada kemampuan spasial dan kemampuan imaginasi peserta didik pada konsep atom dan molekul masih rendah, hal ini disebabkan oleh peserta didik belum pernah melihat bentuk atom yang sebenarnya sama seperti hasil penelitian Abd Halim at al (2013) yang menunjukkan kesulitan belajar ikatan kimia disebabkan peserta didik tergolong lack of knowledge materi atom. Kedua adalah proses pembelajaran kimia yang dilaksanakan cenderung teksbook dan teoritis, belum mengarahkan pada dalam memahami kimia melalui integrasi tiga representasi, yaitu makroskopis, mikroskopis dan simbolis. Pembelajaran kimia yang dimulai dengan diagnostik menggunakan Intrumen ITIK digunakan untuk pemetaan kemampuan awal peserta didik dan dapat digunakan dalam merencanakan proses pembelajaran kimia yang tepat bagi peserta didik.

\section{UCAPAN TERMAKASIH}

Terimakasih kami sampaikan kepada Dekan Fakultas Sains dan Teknologi yang telah memberikan ijin melaksanakan penelitian ini dan LPPM UIN Sunan Kalijaga yang telah mendanai penelitian ini pada tahun 2015 serta semua pihak yang telah membantu terlaksananya penelitian ini baik langsung maupun tidak langsung

\section{DAFTAR PUSTAKA}

Arikunto. (1999).Dasar-dasar Evaluasi Pendidikan (Edisi Revisi). Bandung: Bumi Aksara

Berg, Euwe van den.(1991).Miskonsepsi Fisika dan Remidiasi.Salatiga: UKSW

Brady, J.E. 1999. Kimia Universitas (Asas dan Unsur). Diterjemahkan oleh Sukmariah. Jakarta: Binarupa Aksara.

Driver,R.,Squires, A.,Rushworth,P.,\&WoodRobinson,V.,(1994). Making Sense of Secondary Science, Research Into Children's Ideas.Driver,R.,Squires. New York: Routledge.

Gall, J., Borg. W., \& Gall, M. (2003). Educational research: An introduction (7th ed.). Boston: Pearson Education

Horton, C., et al. (2004). Student Altenative Conceptions in Chemistry (Originally : Student Misconceptions and Preconceptions in Chemistry). Modeling Instruction in High School Chemistry Action Research Teams at Arizona State University, diunduh pada tanggal 28 Desember 2011, dari http://www.daisly.net/hellevator/miscon ceptions/misconceptions.pdf

Maria Evagorou, Sibel Erduran, Terhi Mantyla. (2015). The Role of Visual representations in scientific practices: from conceptual understanding and knowledge generation to seeing how 
science work. International Journal od STEM Education 2:11. Springer.

Musfata Tuysuz., B, Ekiz., O, Bektas., E,Uzunteryaki., A,Tarkin., E,S,Kutucu., (2011). Pre-service Teachers' understanding of phase changes and dissolution at macroscopic, symbolic, microscopic level. Procedia: Social and Behavioral Science 15 page 452-455. Publisher Elsevier.

Noor Dayana Abd Halim., M.Bilal Ali., N, Yahaya, M,N, Haruzuan M,Said. (2013). Mental Model in Learning Chemical Bonding: A. Preliminary Study. Procedia: Sosial and Behavioral Science 97 page 224-228.

Paul Suparno. (2005). Miskonsepsi dan Perubahan Konsep Pendidikan Fisika. Gramedia: Jakarta

Pesman, Haki. (2005). Development of a three-tier test to asses ninth grade Student misconceptions about simple electric circuits. Tesis Master, Middle East Technical University, Turkey
Putu Indrayani. (2013). Analisis pemahaman makroskopis, mikroskopis, dan simbolik titrasi asam basa siswa kelas XII IPA SMA serta upaya perbaikannya dengan pendekatan mikroskopis. Jurnal Pendidikan Sains Vol 1 No.2 Hal 109-120.

Sarikaya, Mustafa. (2007). Prospective Teachers' Misconceptions About The Atomic Structure in The Context of Electrification by Friction and an Activity in Order to Remedy Them. International Education Journal, 2007, $8(1), 40-63$

Sukarjo \& Sari, Lis. P. (2008). Penilaian Hasil Belajar Kimia. Yogyakarta : UNY

Suparno, Paul. (2005). Miskonsepsi \& Perubahan Konsep Pendidikan Fisika. Jakarta: Grasindo 